\title{
Erratum to: A contrast among farmers' ethnic groups: is this a social polarization tendency?
}

Sitti Aida Adha Taridala ${ }^{1}$, Nur Isiyana Wianti ${ }^{2}$, Muhammad Arsyad ${ }^{3}$, and Arifiana Shima Ekaputri ${ }^{4}$

${ }^{1}$ Department of Agribusiness, Faculty of Agriculture, University of Halu Oleo, Kendari 93232, Indonesia

${ }^{2}$ Department of Agricultural Extension, Faculty of Agriculture, University of Halu Oleo, Kendari 93232, Indonesia

${ }^{3}$ Department of Agricultural Socio-economics, Faculty of Agriculture, Hasanuddin University, Makassar 90245, Indonesia

${ }^{4}$ Marketing Department, University of Birmingham, United Kingdom

Original article: E3S Web of Conferences 52, 00044 (2018), https://doi.org/10.1051/e3sconf/20185200044

The first author name should be replaced by the following text:

Sitti Aida Adha Taridala 